\title{
ZAŠTITA PISANE BAŠTINE \\ U ZAJEDNICI AKM-A (ARHIVI-KNJIŽNICE-MUZEJI): \\ FRANJO KSAVER KUHAČ (1834.-1911.) - UTEMELJITELJ \\ HRVATSKE ETNOMUZIKOLOGIJE I GLAZBENE HISTORIOGRAFIJE
}

\author{
THE PRESERVATION OF WRITTEN HERITAGE \\ IN THE ALM (ARCHIVES-LIBRARIES-MUSEUMS) \\ COMMUNITY: FRANJO KSAVER KUHAČ (1834 - 1911)- \\ THE CREATOR OF THE CROATIAN ETHNOMUSICOLOGY \\ AND MUSIC HISTORIOGRAPHY
}

Branka Radić

Sveučilište u Splitu

branka.radic@unist.hr

\author{
UDK / UDC \\ 025.85:[026/028::069::930.25] Kuhač, F.K. \\ Pregledni rad / Review paper \\ Prihvaćeno / Accepted: 14. 3. 2017.
}

\section{Sažetak}

Svrha je ovog rada kvalitetna prezentacija i prepoznavanje vrijednosti pisane baštine pohranjene u baštinskim ustanovama u povodu stote obljetnice preminuća Franje Ksavera Kuhača (1843.-1911.), začetnika folkloristike, etnomuzikologije i muzikologije u hrvatskoj glazbenoj kulturi. Sustavna i sveobuhvatna zaštita dostupnosti informacija podrazumijeva zajedničku aktivnost na strateškoj, tehničkoj i operativnoj razini s ciljem stvaranja oblika obrazovanja unutar akademske zajednice, ustanova od strateškog i kulturnog značenja te operativnih ustanova. Strategija aktivnog upravljanja zaštitom obuhvaća pet temeljnih vidova, učinkovito

Vjesnik bibliotekara Hrvatske 60, 2-3(2017), 25-45

ISSN 0507-1925

(C) VBH 2017. 
djelovanje usmjereno je na dobrobit baštinskih zbirki koje se smatraju hrvatskim kulturnim dobrom.

Ključne riječi: pisana baština, zaštita dostupnosti informacija, Franjo Ksaver Kuhač, suradnja u AKM-zajednici, upravljanje zaštitom

\section{Summary}

The purpose of this paper is to present the Croatian written heritage in the most suitable way and to recognize the value of the written heritage which is kept and preserved in Croatian heritage institutions on the occasion of the hundredth anniversary of Franjo Ksaver Kuhač's death, the man who was the creator of folkloristics, ethnomusicology, and musicology in the Croatian music culture. The systematic and comprehensive preservation of the information availability implies cooperation and joint activities on the strategic, technical, and operative levels with the purpose of creating adequate forms of education within the academic community, institutions of strategic value, laboratories, and operative institutions. The strategy of active preservation management includes five basic aspects, and the efficient management is aimed at the well-being of the heritage collections that are considered to be the Croatian cultural property.

Keywords: written heritage, preservation of information availability, Franjo Ksaver Kuhač, cooperation in ALM community, preservation management

\section{Uvod}

Pisana kulturna baština ${ }^{1}$ određena je skupina jedinica koje se mogu pojaviti u bilo kojem obliku i u sebi sadrže baštinsku vrijednost (objekti, zamisli, osjećaji, materijalni objekti, pisani tekst i dr.). Stvorena je u prošlosti s namjerom da se očuva za buduće naraštaje i pohranjena je na papiru.

"UNESCO ističe otvoreni koncept baštine koji odražava ne samo prošlu, nego i sadašnju živuću kulturu i usmjerava pritom pozornost ne samo na ljudsko društvo, njegove tradicije i izričaje, nego i na informacijske, društvene i filozofske sustave na kojima se stvaralaštvo temelji." ${ }^{2}$

Proučavanje problematike zaštite u suradničkim ustanovama započinje odgovaranjem na temeljna pitanja o tome zašto trebamo zaštitu, što zapravo štitimo, od koga/čega, s kojim ciljem ili svrhom, tko se sve bavi zaštitom i sl. Sustavne i sveo-

\footnotetext{
1 Krtalić, Maja; Damir Hasenay; Tatjana Aparac-Jelušić. Upravljanje zaštitom pisane baštine u knjižnicama - teorijske pretpostavke. // Vjesnik bibliotekara Hrvatske 54, 1/2 (2011), str. 3.

2 Isto.
} 
buhvatne mjere zaštite poduzimaju se s ciljem postizanja učinkovitog upravljanja i detaljne organizacije, naročito u novom digitalnom okruženju, što uključuje jasno definiranje svrhe i cilja primjene zaštite:

- najučinkovitije razine zaštite te suodnos s ostalim razinama

- okviri u kojima su mjere provedive

- koncept zaštite

- kriteriji selekcije, vrednovanja i užeg odabira

- najprimjereniji pristupi i metode,

- posljedice koje proizlaze iz primijenjene zaštite.

Teorijski okvir upravljanja zaštitom predstavlja polazišnu točku u proučavanju konteksta zaštite kao sastavnog dijela poslovanja knjižnica, ali i ostalih informacijsko-baštinskih ustanova koje u svakom trenutku moraju imati uvid u kvalitativno i kvantitativno stanje svojih zbirki, kao i u potrebe za njihovim korištenjem.

Metodologija ovog rada usmjerena je na brzo i djelotvorno prikupljanje podataka o vrsti materijalne građe i njihovu kvalitetnu prezentaciju s ciljem uvida u opće stanje fondova i prepoznavanje vrijednosti pisane baštine pohranjene u baštinskim ustanovama.

\section{Zaštita dostupnosti informacija - razine}

Definicija pojma „zaštita“ obično obuhvaća sva upravna, administrativna, financijska i kadrovska pitanja bitna za očuvanje i dobrobit knjižničnih zbirki, postizanje određenog stupnja sigurnosti, nadzora nad okolinom, pohranu, čuvanje i postupanje kako bi se spriječilo daljnje kemijsko propadanje i kako bi se knjižnična građa zaštitila od mehaničkih oštećenja (dobrobit knjižnične zbirke). ${ }^{3}$ Zaštita dostupnosti informacija bavi se pojmovima pouzdanog i dugoročnog. Pouzdanost u odnosu na dostupnost i očuvanje informacija ${ }^{4}$ odnosi se na autentičnost informacija njihovu izvornom obliku kod pohranjivanja, njihovu sigurnu upotrebljivost s obzirom na vremensku kategoriju i namjenu. Dugoročnost se promatra kao planirana aktivnost u prostoru i vremenu s ciljem osiguravanja dostupnosti i očuvanja informacija. U kontekstu otpornosti na promjene razmatraju se prirodne zakonitosti materijalnog nositelja informacije s obzirom na vrstu materijala i njihovo

\footnotetext{
3 IFLA-ina načela za skrb i rukovanje knjižničnom građom / sastavio i uredio Edward P. Adcock u suradnji s Marie-Theresom Varlamoff i Virginiom Kremp. Zagreb : Hrvatsko knjižničarsko društvo, 2003. Str. 11.

4 Hasenay, Damir; Maja Krtalić. Dostupnost i očuvanje informacija - što znači pouzdano i dugoročno? // 12. seminar Arhivi, knjižnice, muzeji: mogućnosti suradnje u okruženju globalne informacijske infrastrukture: zbornik radova / uredila Sanjica Faletar Tanacković. Zagreb : Hrvatsko knjižničarsko društvo, 2008. Str. 2. [cititrano: 2016-04-05]. Dostupno na http://public.carnet.hr/ akm/AKM_ostali/AKM12/AKM\%2012.htm.
} 
propadanje. Svrha je zaštite (pisana baština - formati zapisa - materijali) očuvati neku jedinicu građe za buduće naraštaje, što podrazumijeva trajno čuvanje.

Organizacijske i materijalne pretpostavke dostupnosti i očuvanja informacija moguće je promatrati na tri razine. Ako se zaštita promatra kao aktivnost koju je potrebno planirati i organizirati na nacionalnoj i međunarodnoj razini, govorimo o strateškoj razini (fizička zaštita nositelja informacije, a zatim i zaštita intelektualnog sadržaja) koja obuhvaća predlaganje inicijativa, pokretanje projekata, organizaciju obrazovanja za stručnjake koji se bave problemima zaštite.

„Svijest o odgovornosti za zaštitu knjižničnih zbirki, kako javnosti tako i onih koji su dužni financirati programe zaštite. Da bi se nacionalna baština sačuvala potrebno je koordinirati nacionale, regionalne, konzorcijske i institucionalne programe zaštite. Vlade trebaju imati odgovornu aktivnu ulogu u osiguravanju dobrobiti za nacionalnu baštinu. Nacionalni uredi za zaštitu, bilo da se financiraju vladinim ili privatnim sredstvima, prijeko su potrebni za očuvanje nacionalne baštine na bilo kojem mediju. Oni bi trebali poticati sve knjižnice i ustanove na usvajanje čvrste politike zaštite. ${ }^{\text {"5 }}$

Tehnička razina uključuje stručno-znanstvenu problematiku povezanu sa specifičnostima materijala i čimbenicima koji ih ugrožavaju uz pomoć tehničkih metoda i postupaka zaštite materijalnih nositelja informacija (primjena konzervatorskih načela, specifičnosti i sastavi pojedinih materijala, tehničke metode i postupci zaštite digitalnih informacija, mikroklimatski, kemijski i biološki čimbenici). Operativnom razinom bave se stručnjaci koji se u svom radu svakodnevno skrbe o prikupljanju, pohrani, čuvanju i organizaciji informacija, kriterijima za vrednovanje, procjeni i odabiru pojedinih objekata za upućivanje na neku drugu razinu zaštite te radu s korisnicima i njihovoj pravilnoj edukaciji. ${ }^{6}$ Materijalne pretpostavke dostupnosti i očuvanja informacija odnose se na odabir koncepta zaštite (svojstva materijalnih nositelja informacija). Zaštita analognih dokumenata, u što ubrajamo papirnu građu, usmjerena je na metode pomoću kojih postižemo fizičku i kemijsku stabilnost, a samim time i kvalitetu i trajnost materijala (struktura i svojstva vlakana od kojih je papir proizveden). Važno je istaknuti preventivnu zaštitu čiji je cilj usporavanje procesa prirodnog starenja uz primjenu metoda koje

\footnotetext{
5 IFLA-ina načela za skrb i rukovanje knjižničnom građom. Nav. dj. Str. 16.

6 U organizaciji NSK-a: Centar za stalno stručno obrazovanje knjižničara, u Gradskoj knjižnici Marko Marulić u Splitu održana je jedna od prvih radionica o zaštiti građe (listopad 2011.). Tema je bila „Planiranje i upravljanje zaštitom knjižnične građe“. Godišnji program trajne izobrazbe namijenjen je knjižničarima iz svih vrsta knjižnica, knjižničnom osoblju, kao i informacijskim stručnjacima u baštinskim ustanovama. Osnovni cilj navedene problematike jesu sagledavanje stanja i percepcije zaštite, ključni pojmovi za bolje razumijevanje i okviri koji dovode do korištenja iste terminologije (povezanost visokoškolskog obrazovanja sa stalnim stručnim usavršavanjem - jačanje uloge sveučilišta donošenjem znanstvenih strategija).
} 
će spriječiti odvijanje štetnih ${ }^{7}$ promjena kao što su restauriranje i konzerviranje. Zaštita digitalnih dokumenata bitno se razlikuje od zaštite papirne građe. Problemi koji nastaju u svakodnevnom radu najčešće su tehničke i organizacijske prirode. Pod tehničkim problemima podrazumijeva se zastarijevanje tehnologije (potrebna je redovita migracija), fizičko propadanje digitalnih medija (potrebna je pravilna pohrana), nedovoljno razvijeni standardi za opis i pohranu digitalnih dokumenata i korisničke potrebe (je li nešto zastarjelo zato što korisnici to ne žele upotrebljavati iako je tehnološki uporabljivo, npr. mikrofilm). Kod zaštite mrežnih dokumenata problem predstavlja i nestabilnost lokacije. Odgovor možemo pronaći u ažuriranju i migraciji na stabilnije medije, odnosno u organizacijskim pretpostavkama digitalne zaštite.

Odabir građe za zaštitu može se temeljiti na učestalosti korištenja, specifičnosti sadržaja dokumenta, autoru, razdoblju te stanju dokumenta, kao i nizu drugih mjerila $^{8}$. U smjernicama za odabir građe koju je potrebno zaštititi, nastalim unutar niza projekata zaštite, možemo razlikovati mjerila odabira građe za digitalizaciju u svrhu zaštite (stupanj oštećenja građe) i u svrhu korištenja (zahtjevi za korištenjem zbirki). Kriteriji odabira publikacija u digitalnom obliku za zaštitu trebali bi biti utemeljeni na postojećim kriterijima zaštite za tradicionalne medije. Problemi nastaju tijekom razvoja ${ }^{9}$ i promjene digitalnih oblika te stabilnosti medija za njihovu pohranu. Prisutna je potreba za sustavnim isprepletanjem aktivnosti u zaštiti na strateškoj, tehničkoj i operativnoj razini. Pouzdanost zaštite osnovnih svojstava pisane baštine, tj. informacija koje ona sadrži - čitljivost, materijalna konfiguracija određenog objekta - temeljna je osnova procesa i aktivnosti koje se poduzimaju da bi knjiga, spis ili CD ostali što dulje u upotrebi zadržavanjem svojstava osnovnog materijala.

\section{Suradnja u zajednici arhiva, knjižnica i muzeja}

Projekt Franjo Ksaver Kuhač (1834.-1911.) pokrenut je 2009. godine s namjerom prikupljanja, očuvanja i promicanja uglednog hrvatskog istraživača i utemeljitelja znanosti o glazbi u Hrvatskoj. Mrežni portal „Franjo Ksaver Kuhač“10 djelo je suradničkog rada članova Hrvatske udruge muzičkih knjižnica, arhiva i

\footnotetext{
7 Uzroci oštećenja mogu biti vlaga, toplina, atmosferski i kruti zagađivači, svjetlost i biološki uzroci (plijesni, kukci, glodavci).

8 Usp. IFLA. Guidelines for digitization projects for collections and holdings in the public domain, particularly those held by libraries and archives, 2002. [citirano: 2016-04-05]. Dostupno na http://www.kultura.hr/Sudjelujte/Digitalizacija/Korisni-linkovi.

9 Usp. The NINCH guide to good practice in the digital representation and management of cultural heritage materials, 2002. [citirano: 2016-04-05]. Dostupno na http://www.kultura.hr/Sudjelujte/Digitalizacija/Korisni-linkovi.

10 Usp. Mrežni portal Franjo Ksaver Kuhač. [citirano: 2016-04-06]. Dostupno na http://kuhac. net/index.html.
} 
dokumentacijskih centara. ${ }^{11}$ Projekt je ostvaren sredstvima Ministarstva kulture i dio je nacionalnog projekta digitalizacije arhivske, knjižnične i muzejske građe „Hrvatska kulturna baština““. ${ }^{12}$ Baštinska građa obuhvaća razdoblje 19. i 20. stoljeća i sadrži: arhivsko gradivo - preslike knjiga, notnih zapisa, dokumenata i pisama; digitalne zapise - fotografije i zvučne snimke; digitalne formate - .swf, .pdf, .jpg, .mp3 i .wav. Može se naći na više lokacija u Hrvatskoj: Hrvatski državni $\operatorname{arhiv}^{13}$ u kojem se čuva osobni fond Franje Ksavera Kuhača; Arhiv Hrvatske akademije znanosti i umjetnosti (HAZU) ${ }^{14}$ u kojem je pohranjena Kuhačeva glazbena biografska građa. U Knjižnici Odsjeka za povijest hrvatske glazbe Hrvatske akademije znanosti i umjetnosti čuva se različita građa iz ostavštine Ladislava Šabana (bilješke, pisma, radovi o Kuhaču, izvješća o uređivanju ostavštine Kuhač u HDA, dopisi i razna građa u vezi s objavljivanjem 1. i 2. sveska Kuhačeve korespondencije); u Muzeju Slavonije Osijek ${ }^{15}$, Hrvatskom glazbenom zavodu ${ }^{16} \mathrm{u}$ čijoj knjižnici se čuvaju Kuhačevi autografi i knjige, a u arhivu različita dokumentacija i spisi; Nacionalna i sveučilišna knjižnica ${ }^{17}$ u Zbirci rukopisa i starih knjiga čuva autografe Kuhačevih tekstova, korespondenciju i kompozicije. Muzej grada Zagreba ${ }^{18}$ u kojem se čuvaju osobni predmeti iz Kuhačeve ostavštine; Institut za etnologiju i folkloristiku ${ }^{19}$; Etnografski muzej ${ }^{20}$ čuva zbirku glazbenih instrumenata. Najvredniji dio kolekcije čini zbirka od 56 primjeraka koje je Kuhač prikupio i

11 Usp. HUMKAD. [citirano: 2016-04-06]. Dostupno na http://www.humkad.hr/. Glazbeni materijali kojima se društvo bavi obuhvaćaju najrazličitije medije. Sadržaj je sljedeći: tekstovi o glazbi - knjige, časopisi; notni zapisi - tiskane muzikalije, časopisi; zvučni zapisi - svi strojno čitljivi mediji, kompaktni diskovi (CD), audio DVD, zvučne kasete, gramofonske ploče; dokumentarni i igrani filmovi o glazbi i glazbenicima; videosnimke koncerata; sva računalno čitljiva građa - edukativni glazbeni programi, glazbene enciklopedije, notni zapisi.

12 Usp. Hrvatska kulturna baština. [citirano: 2016-04-06]. Dostupno na http://kultura.hr/hr/Zbirke/Franjo-Ksaver-Kuhac.

13 Usp. Hrvatski državni arhiv. [citirano: 2016-04-06]. Dostupno na http://arhinet.arhiv.hr/_Generated/Pages/ArhivskeJedinice.PublicDetails.saps?ItemId=4722.

14 Usp. Digitalna zbirka Knjižnice HAZU - jedinstveni repozitorij u kojem se pohranjuje digitalizirana građa iz 14 Akademijinih istraživačkih i muzejsko - galerijskih jedinica. [citirano: 201604-06]. Dostupno na http://dizbi.hazu.hr/.

15 Usp. Muzej Slavonije Osijek. [citirano: 2016-04-06]. Dostupno na http://www.mso.hr/index. php?page=naslovna.

16 Usp. Hrvatski glazbeni zavod. [citirano: 2016-04-06]. Dostupno na http://www.hgz.hr/.

17 Usp. Nacionalna i sveučilišna knjižnica. Zbirka rukopisa i starih knjiga. [citirano: 2016-0406]. Dostupno na http://www.nsk.hr/zbirka-rukopisa-i-starih-knjiga/.

18 Usp. Muzej grada Zagreba. [citirano: 2016-04-06]. Dostupno na http://www.mgz.hr/hr/naslovnica/.

19 Usp. Institut za etnologiju i folkloristiku. [citirano: 2016-04-06]. Dostupno na http://www.ief. hr/OInstitutu/Povijest/tabid/70/language/hr-HR/Default.aspx.

20 Usp. Etnografski muzej. [citirano: 2016-04-06]. Dostupno na http://www.emz.hr/zbirke.html. 
sustavno proučavao između 1857. i 1886. godine; Muzička akademija Zagreb ${ }^{21} \mathrm{u}$ katalogu svoje knjižnice čuva značajan broj Kuhačevih objavljenih djela - kompozicija, teorijskih i muzikoloških radova; u Knjižnicama grada Zagreba Gradska knjižnica ${ }^{22}$ posjeduje brojna izdanja Kuhačevih djela, a neka su i digitalizirana u okviru projekta „Digitalizirana zagrebačka baština“; Virtualni muzej tradicijske glazbe Međimurja. ${ }^{23}$

Suradnja u zajednici AKM-a (arhivi, knjižnice, muzeji), kada je u pitanju zaštita na strateškoj razini, prisutna je u obliku realizacije projekta „Franjo Ksaver Kuhač”, i to između Ministarstva kulture, Nacionalne i sveučilišne knjižnice, Hrvatskog državnog arhiva i Hrvatskog društva knjižničara. Isto tako prisutna je savjetodavna i edukativna suradnja između navedene udruge, muzeja, visokoškolske ustanove, knjižnica, zavoda i instituta. Međuinstitucionalna povezanost, pogotovo kada rezultira uspješnim projektom, pokazuje kvalitetnu suradnju u organizaciji zbirki i njihovu pravilnom vrednovanju na operativnoj razini. Na takav način izbjegava se nepotrebno udvostručavanje poslova, značajna ušteda novčanih sredstava na tehničkoj razini i, ono najvažnije, razvijanje svijesti o poimanju zaštite kao zajedničkog problema svih ustanova.

Aktivnosti politike zaštite vidljive su u izražavanju namjere, znakovima pouzdanosti i definiranju odgovornosti vodstva, osoblja i korisnika neke ustanove. Vidljive su i kod zagovaranja o prikupljanju financijskih sredstava, razvoja strategija zaštite te kao mjerilo kvalitete uspješnosti i vrednovanja postignutog.

U nastavku rada ukratko je prikazan Kuhačev život i rad, prezentacija podataka $\mathrm{s}$ ciljem uvida u opće stanje fondova te njegov doprinos u odnosu na navedeno razdoblje sa svrhom prepoznavanja vrijednosti pisane baštine pohranjene $u$ baštinskim ustanovama.

\section{Franjo Ksaver Kuhač (1834.-1911.) - utemeljitelj hrvatske glazbe- ne historiografije}

Odabravši glazbu za svoj životni poziv, Franjo Ksaver Kuhač tijekom života dugo je izgrađivao svoje pretpostavke, provjeravajući ih i povezujući uz pomoć stečenog znanja, iznimne marljivosti, nesebičnosti i krajnjeg samoprijegora. Svojim mnogobrojnim radovima uspio je izgraditi velik autoritet u domovini i inozemstvu. Hrvatska glazbena kultura u tom razdoblju, upravo djelovanjem Kuhača i Zajca, dosegnula je vrlo visoku umjetničku razinu.

\footnotetext{
${ }_{21}$ Usp. Muzička akademija Zagreb. [citirano: 2016-04-07]. Dostupno na http://www.muza. unizg.hr/index.php?option=com_content\&view=article\&id=77\&Itemid=191.

22 Usp. Knjižnice grada Zagreba. [citirano: 2016-04-07]. Dostupno na http://kgzdzb.arhivpro. $\mathrm{hr} /$ ?sitetext=321.

${ }^{23}$ Usp. Virtualni muzej tradicijske glazbe Međimurja. [citirano: 2016-04-07]. Dostupno na http://www.mtraditional.com/kuhac.html.
} 
Zaslugom ilirskog pokreta (1835.-1849. $)^{24}$ potaknut je napredak ekonomskih i društveno-političkih prilika u gradu Osijeku. Kulturnom razvoju doprinosi pojava novina: Novine horvatske (1835.) koje se kasnije nazivaju Ilirske narodne novine i izlaze na štokavskom jeziku, a važnim događajem smatra se i osnivanje Hrvatsko-slavonskog književnog društva te uvođenje katedre za narodni jezik u gimnazijama i na Akademiji. U glazbenom životu istaknuta ličnost bio je barun Karlo Prandau, a zabilježen je i osobito vrijedan rad osječkih tamburaša na čelu s Pajom Kolarićem. Nakon otvaranja kazališne dvorane 1774. godine priređuju se javni koncerti na kojima muziciraju i poznati glazbenici iz inozemstva, omogućivši tako dovoljno kulturnih događanja u gradu, kao i širenje glazbene umjetnosti na međunarodnoj razini.

U takvim uvjetima živio je i Franjo Ksaver Kuhač, čije razdoblje života možemo promatrati kroz četiri dijela: od 1834. do 1848. - vrijeme djetinjstva i školovanja; od 1848. do 1858. - vrijeme odlaska u Pečuh i obavljanja priprema za dugogodišnju naobrazbu i završavanje općeg pedagoškog obrazovanja, završavanje studija i stjecanje iskustva u pedagoškoj praksi; od 1858. do 1871. - putovanje Hrvatskom i susjednim zemljama i sabiranje narodnih napjeva, pedagoško djelovanje, objava glazbenih udžbenika na hrvatskom jeziku, pisanje prvih rasprava na temu narodnih napjeva; od 1871. do 1911. - ocjenjivanje prilika i zbivanja u hrvatskom glazbenom životu tog vremena na svim razinama glazbene produkcije i reprodukcije. Na važnost terminologije upozorio je već u 19. stoljeću, uočivši oskudicu hrvatskih glazbenohistoriografskih izvora. Istaknuo je sljedeće:

„No ako i ne imademo historičkih bilježaka u formi viesti ili pripovietke, nalazimo ih u samom hrvatskom jeziku na obilju. U njem imade toliko glazbenih termina, da po ovima lako prosuditi možemo opseg stare glazbene prakse Hrvata, jer prepoznata je istina, da svaki narod imade samo za one stvari rieči i nazive, koje pozna." ${ }^{25}$

\subsection{Biografija}

\section{Razdoblje od 1834. do 1848.}

Rodio se 20. studenog 1834. godine u Osijeku. Roditelji su mu bili podrijetlom Nijemci s prezimenom Koch (to je prezime nosio i Kuhač sve do 37. godine života). Iz Mađarske su se preselili u Osijek radi sklapanja braka (1828.), da bi se potom nastanili u Tvrđi. Sa šest godina pošao je u Hauptschule (njemačka osnovna škola) gdje završava tri razreda, a 1844. godine upisuje latinsku gimnaziju koju

24 Rakijaš, Branko. Franjo Ks. Kuhač : život i rad. Zagreb : Prosvjetni sabor Hrvatske, 1974. Str. 7-9.

25 Županović, Lovro. Ilirski glazbenici: prilozi za poviest Hrvatskoga preporoda. Pretisak izd. iz 1893. godine. Zagreb : Hrvatska sveučilišna naklada, 1994. Str. LVIII. 
su vodili franjevci. Glazbom se počeo baviti pohađajući privatne satove gitare, violine i klavira.

Razdoblje od 1848. do 1858.

1848. godine otac ga šalje u Donji Miholjac, gdje mu je mentor bio Joseph Beck koji ga priprema za učiteljsko zvanje te mu daje poduke iz sviranja violine, glasovira, orgulja i harmonije potičući i njegovu sklonost sabiranju narodnih napjeva. U Pečuh je otišao 1852. godine; u tom gradu živio je njegov stric Filip Koch, ugledni profesor teologije i filozofije, koji mu pronalazi pripravničko mjesto u učiteljskoj školi. Uz rad upisuje i Učilište muzičkog udruženja (Hangaszegyesuleti Zenede - kasnije konzervatorij) u klasi cijenjenih glazbenika i pedagoga Fr. Erkela i A. Marxa (klavir) te Karla Therna (kontrapunkt i kompozicija). Od 1855. godine privremeno živi u Osijeku, ali i putuje po europskim kulturnim središtima. Tako boravi u Leipzigu, Weimaru (gdje posjećuje F. Liszta) i Beču, gdje neko vrijeme uči glasovir kod C. Czernyja i ujedno sluša na sveučilištu predavanja iz glazbene povijesti i estetike kod poznatog pisca i kritičara Eduarda Hanslicka (1825.-1904.)

Razdoblje od 1858. do 1871.

Smrću njegova strica nasljeđuje znatnu svotu forinti, što mu omogućuje nesmetano ostvarenje njegova velikog djela. Idućih godina putuje po slavenskim zemljama na Balkanu i susjednim državama (Austrija, Istra, Hrvatsko primorje, sjeverna Hrvatska, Međimurje, Mletačka, Lombardija, Bosna i Hercegovina, Srbija, Makedonija, dio Bugarske, Dalmacija i Hercegovina, Ugarska) prikupljajući narodne napjeve, prijepise starih pjesmarica i ostalu etnografsku građu. Dugogodišnjim prikupljanjem građe Kuhač je stvorio zbirku od 4000 napjeva.

„Putovao sam dvanaest godina, svake godine po pet, šest i više mjeseci, te potrošio na to sav svoj imetak, a to nije bila mala svota novca. Prvog siječnja 1870. godine počeo sam izrađivati sakupljene popievke, harmonizirajuć ih i dodavajuć im klavirsku pratnju, te prepisujuć pojedinim tekstovima variante, izvođene iz do onda štampanih pjesmarica." ${ }^{\prime 26}$

U tom vremenu sudjelovao je i u kulturnom životu svoga grada, pa je tako 1861. godine osnovao prvo hrvatsko pjevačko društvo s kojim izvodi djela slavenskog zborskog repertoara (kasnije se razvija u ugledno osječko pjevačko društvo „Kuhač“). Počasni član Narodnog zemaljskog glazbenog zavoda u Zagrebu postaje 1864. godine. U narednom razdoblju bavio se privatnom podukom i komponiranjem, bio je dirigent pjevačkih zborova i tamburaških orkestara te učitelj pjevanja u klasičnoj gimnaziji (1867.-1869.).

26 Rakijaš, Branko. Franjo Ks. Kuhač - život i rad. Nav. dj. Str. 15. 
Razdoblje od 1871. do 1911.

U Zagreb se definitivno preselio 1971. godine, kada službeno mijenja svoje dotadašnje prezime Koch u Kuhač. Uz bogatu publicističku djelatnost (postao je novinarski kritičar kazališnih glazbenih priredaba), imenovan je za profesora klavira, glazbene teorije i kompozicije u školi Narodnog zemaljskog glazbenog zavoda. Također postaje i počasni član pjevačkog društva „Kolo“. Na Svjetskoj izložbi u Beču 1873. godine sudjelovao je sa „Sbirkom Franje Kuhača-Kocha“ i dobiva veliku medalju za svoj izloženi rad sastavljen od narodnih glazbenih instrumenata, plesova te dijelova zbirke pjesama. Godine 1876. daje ostavku na položaj podravnatelja i učitelja u Glazbenom zavodu zbog neslaganja s ravnateljem Karlom Klobučarićem. Ostavka mu je prihvaćena i za njega od tada počinje teško razdoblje života kao za „slobodnog umjetnika“. Za života, Franjo Kuhač bio je sljedbenik ideoloških smjernica koje su započeli Gajevi ilirci. Iako nije uspio ući u redove članova JAZU, svojim radovima stekao je velik ugled u domaćoj i međunarodnoj muzikološkoj javnosti te postavio temelje nacionalnoj glazbenoj historiografskoj literaturi. Umro je u Zagrebu 18. lipnja 1911. godine.

\subsection{Djela}

Plodna znanstvena djelatnost $i$ istraživački interes koji je Franjo Ksaver Kuhač izgrađivao desetljećima na području hrvatske folkloristike, muzičke historiografije, publicistike i kritike rezultirali su opsegom ${ }^{27}$ objavljenih radova i rezultata jedinstvene vrijednosti. Dugogodišnji rad na polju glazbene kulture južnih Slavena obuhvaća pet osnovnih područja $\left.{ }^{28}: 1\right)$ područje etnomuzikologije, odnosno komparativne muzikologije, 2) područje povijesti glazbe, 3) glazbeno-pedagošku djelatnost, 4) posebne vrste djelatnosti te 5) komponiranje vlastitih skladbi.

\subsubsection{Područje etnomuzikologije, odnosno komparativne muzikologije}

Djelovanje na području glazbene kulture južnih Slavena obuhvaća zapisivanje, proučavanje i objavljivanje zapisa vokalne i instrumentalne folklorne glazbe Hrvata i drugih južnih Slavena; istraživanje i proučavanje folklornih glazbala; metode terenskog i istraživačkog i prikupljačkog rada; utvrđivanje primjene napjeva iz folklorne glazbe Hrvata u djelima majstora bečke klasike; proučavanje određenog teksta i napjeva polazeći od rezultata komparativne filologije; komparativno proučavanje hrvatske, mađarske, njemačke i talijanske folklorne glazbe.

27 Usp. Bibliografija radova o Franji Kuhaču. // Zbornik radova sa znanstvenog skupa održanog u povodu 150. obljetnice rođenja Franje Ksavera Kuhača (1834.-1911.). Zagreb : JAZU, 1984. Str. 497-521. [citirano: 2016-04-07]. Dostupno na http://kuhac.net/bibliografija.html.

${ }_{28}$ Bezić, Jerko. Franjo Ksaver Kuhač: začetnik glazbenoznanstvenih djelatnosti u hrvatskoj i u jugoslavenskoj glazbenoj kulturi // Zbornik radova sa znanstvenog skupa održanog u povodu 150. obljetnice rođenja Franje Ksavera Kuhača (1834.-1911.). Zagreb : JAZU, 1984. Str. 7-9. 
Sachliche Einleitung zu der Sammlung sudslavischer Volksliede ${ }^{29}-1873$. godine objavljuje studiju na njemačkom jeziku, gdje objašnjava svoje shvaćanje o stvaranju jugoslavenske umjetničke glazbe temeljene na folkloru. ${ }^{30}$ Tim radom stekao je zaslužena priznanja mnogih uglednih znanstvenika i kritičara u inozemstvu.

Prilog za povijest glazbe južnoslavjanske ${ }^{31}$ (1877.-1882.) - u toj studiji istražuje povijesni razvoj narodnih instrumenata južnih Slavena opisujući starinska folklorna glazbala, pa sve do onih koja su nastajala u tom vremenu i na kojima se muziciralo. Uz svaki instrument navodi sve moguće nazive i citate iz svjetske literature vezane uz postanak i načine sviranja na određenom glazbalu.

Južno-slovjenske narodne popievke ${ }^{32}$ - dvadesetogodišnjim intenzivnim zapisivanjem te proučavanjem vokalne i instrumentalne folklorne glazbe Hrvata i drugih južnih Slavena Kuhač postavlja čvrste temelje za kasnija folkloristička i etnomuzikološka istraživanja. Od 1878. do 1881. godine objavljuje četiri od pet pripremljenih svezaka (1600 narodnih napjeva - po 400 zapisa u svakoj knjizi) zbirke. U I. i II. knjizi prikupljene su Ljubavne popievke iz naših različitih krajeva i susjednih zemalja, u III. knjizi uz ljubavne popjevke objavljene su Sigre odrasle mladeži i Pjesme uz kolo te Plesovi ili tanci, u IV. knjizi sadržane su Svatovske, Napitnice, Šaljive, Sljepačke i Junačke popievke (pričalice i davorije). Petu knjigu objavili su posthumno B. Širola i Vl. Dukat u ožujku 1941. godine. Ona sadrži Popijevke patriotične ili domoljubne, Popijevke o razbojnicima i tatima, Popijevke putničke, Dječje popijevke, Kolede, Žetelačke popijevke, Razne popijevke, Naricanje i naricaljke nad mrtvima, Vilinske i druge mitologijske pjesme.

Die Eigenthumlichkeiten der magyarischen Volksmusik ${ }^{33}$ - studija koja je dovršena 1884. godine, a u kojoj je „komparativna muzikologija“ objašnjena kao znanost koja istražuje značajke glazbenog stila nekog naroda s ciljem definiranja tradicijske glazbe.

Moj rad ${ }^{34}$ - autobiografska brošura nastala 1904. godine. Kuhač ovdje sažima svoja postignuća tijekom pedeset godina rada, analizirajući trideset tisuća melodija (grčke, arapske i crkvene liturgijske melodije rimokatolika, pravoslavaca, luterana, kalvina, muhamedanaca i židova). U kasnijem radu usredotočio se samo na Hrvate,

\footnotetext{
29 [citirano: 2016-04-07]. Dostupno na http://kuhac.net/digiarchive/note/sammlung/index.html Original ustupila Knjižnica Muzičke akademije u Zagrebu.

30 Škunca, Mirjana. Franjo Kuhač kao muzički historičar. // Zagreb: JAZU 351. Odjel za muzičku umjetnost, 1969. Str. 295.

31 Andreis, Josip: Povijest hrvatske glazbe. Knjiga 4. Sveučilišna naklada Liber : Zagreb, 1989. Str. 260

32 Rakijaš, Branko. Nav. dj., str. 28-36.

33 Majer-Bobetko Sanja; Zdravko Blažeković; Gorana Doliner. Hrvatska glazbena historiografija u 19. stoljeću. Zagreb : Hrvatsko muzikološko društvo, 2009. Str. 34-36.

34 [citirano: 2016-04-07]. Dostupno na http://kuhac.net/digiarchive/note/mojrad/index.html. Original ustupila Knjižnica Muzičke akademije u Zagrebu.
} 
Talijane, Nijemce, Mađare i Turke, a tu novu glazbenu znanost nazvao je komparativna muzikologija i prilagodio ju jeziku svog naroda (melodija, ritam, struktura).

Osebine narodne glazbe, naročito hrvatske ${ }^{35}$ (1905.- 1909.) - rasprava je s podnaslovom „Komparativna muzikologija“ nastala kao logičan rezultat njegovih dugogodišnjih nastojanja. Rezultati analize u tom djelu pružaju putokaz za stvaranje umjetničke glazbe nacionalnog karaktera, a odnose se na melodiju, ritam, harmoniju, dinamiku i oblikovanje, strukovnu i izvođačku praksu. Kuhač je glazbenu znanost razdijelio u tri skupine: u prvu skupinu spada semiografija, znanost o harmoniji i ritmu, sintaksi, oblicima, kontrapunktu, kompoziciji, instrumentaciji i glazbenom pravopisu. U drugu skupinu spada tekst pjesme s glazbenog gledišta po jezičnoj melodiji, ritmici, dinamici, tj. po akcentu. U treću skupinu spada uspoređivanje narodne i umjetničke glazbe nekog naroda s glazbom drugih naroda u svrhu saznavanja onih osobina koje narodnoj glazbi daju posebno obilježje u melodiji, ritmu, harmoniji i strukturi s ciljem usavršavanja tradicionalnih pravila. U sporedne struke muzikologije svrstao je akustiku, fiziologiju, pjevala, gradnju glazbala, povijest glazbe, estetiku, poetiku, glazbenu bibliografiju, didaktiku i folkloristiku.

\subsubsection{Područje povijesti glazbe}

Područje povijesti glazbe koje se bavi nacionalnom poviješću glazbe; poviješću razvoja glazbene umjetnosti u svijetu; višegodišnjim prikupljanjima muzikalija i drugih dokumenata o glazbenoj djelatnosti južnih Slavena u proteklim vremenima.

Ilirski glazbenici ${ }^{36}$ - pisanje te monografije započelo je 1863. godine u Osijeku. Tek desetak godina kasnije Matica hrvatska tiska to djelo u kojem je u prvom redu istaknuta vrijednost naše narodne glazbe i njezina uloga u daljnjem razvoju umjetnosti uopće, smisao amaterizma kao temelja glazbenog odgoja čiji su glavni nositelji pučki učitelji, orguljaši i gradski kapelnici, važnost pojavljivanja prvih muzičkih društava i manjih instrumentalnih sastava, uzori u glazbi, naročito njemački, kao nužna prijelazna etapa u razvoju glazbene kulture. Ilirski glazbenici svrstani su u tri grupe: kompozitori, skladatelji i zapisivači. Od kompozitora navedeni su Ferdo Livadić (1799.-1878.), Fortunat Pintarić (1798.-1867.), Karlo Prandau (1793.-1865.) i Mijo Hajka (1820.-1848.). Od kompozitora koji su bili i reproduktivci navedeni su gitarist Ivan Padovec (1800.-1873.), flautist Franjo Ks. Čačković Vrhovinski (1789.-1875.), dirigent Dragutin Turanyi (1806.-1872.) i violonist Franjo Pokorny (1825.-1859.). Od narodnih umjetnika tu su Ferdo Rusan (1810.-1879.), Pajo Kolarić (1821.-1876.) i Josif Runjanin (1821.-1878.). Od ostalih umjetnika spomenuti su Vjekoslav Karas (1821.-1858.), Vatroslav Vernak (1824.-1863.) i Pavao Stoos (1806.-1862.). Kao sakupljači narodnih crkvenih i

\footnotetext{
35 Majer-Bobetko Sanja; Zdravko Blažeković; Gorana Doliner. Nav. dj., str. 34-36.

36 Rakijaš, Branko. Nav. dj., str. 43-45.
} 
svjetovnih pjesama navedeni su Marijan Jaić (1790. - 1858.) i Stanko Vraz (1810. - 1851). I na kraju. primadona prve hrvatske opere Ljubav i zloba Sidonija Rubido-Erdody (1819.-1884.).

Versuch einer Musikgeschichte der Sudslaven ${ }^{37}-1875$. godine tekst je napisan na njemačkom jeziku, zapisano je Kuhačevo razmišljanje o cjelokupnom opsegu povijesti glazbe kao discipline. Sinopsis povijesti objavljen je u „Viencu“ kao „Pokus glasbene poviesti južnih Slavena“. Opsežan program tog djela proizašao je iz njegovih objavljenih i neobjavljenih radova na svim područjima ${ }^{38}$ kojima se bavio.

Vatroslav Lisinski i njegovo doba ${ }^{39}$ - prvo izdanje izdala je Matica Hrvatska 1887. godine. Drugo dopunjeno izdanje objavljeno je 1904. godine, a monografija oživljava lik Lisinskog, umjetnika kojem je Kuhač bio neobično privržen. To djelo jedno je od najznačajnijih djela napisanih o našim glazbenicima sudeći prema vrijednosti podataka prema kojima se moglo rekonstruirati ambijent, događaje, likove i duh vremena kompozitora. Za Kuhača je Lisinski u svom umijeću pretekao svoje doba i svoje učitelje.

Glazbeno nastojanje Gajevih Ilira ${ }^{40}$ - brošura s kratkim pregledom povijesnog razvoja glazbenih nastojanja u sjevernoj Hrvatskoj, s posebnim osvrtom na razdoblje ilirizma i na slovenske, srpske, dalmatinske i strane glazbenike te osobe koje su pridonijele širenju nacionalnih ideja.

\subsubsection{Glazbeno-pedagoška djelatnost}

Svoj rad na tom području Kuhač je temeljio na prijedlogu plana za osnivanje „Narodnog glasbenog sveučilišta“ u Zagrebu, na prijevodu knjige Katechismus der Musik $k^{41}$ J. Chr. Lobea - stvaranje hrvatske glazbene terminologije - i objavljivanju Prve hrvatske upute u glasoviranje za djecu i odrasle samouke, priručnika za nastavu klavira - uz primjenu primjera iz folklorne glazbe Hrvata i drugih južnih Slavena.

Katekizam glazbe ${ }^{42}$ - prvo izdanje prijevoda knjige Katechismus der Musik izašlo je u Zagrebu 1875. godine u nakladi Dragutina Albrechta. Posvećeno je

\footnotetext{
37 Majer-Bobetko Sanja; Zdravko Blažeković; Gorana Doliner. Nav. dj., str. 39.

38 Katalinić, Vjera. Povijest hrvatske glazbe u razdoblju klasike - sto godina historiografskih istraživanja, ideja i sinteza: od Franje Ksavera Kuhača do Josipa Andreisa. // Zbornik radova sa znanstvenog skupa održanog u povodu 150. obljetnice rođenja Franje Ksavera Kuhača (1834.1911.). Zagreb : JAZU, 1984. Str. 473-495. [citirano: 2016-04-07]. Dostupno na http:// http:// kuhac.net/bibliografija3.html.

39 Škunca, Mirjana. Nav. dj., str. 312.

40 [citirano: 2016-04-07]. Dostupno na http://kuhac.net/digiarchive/note/gajevi\%20iliri/index. html Original ustupio Hrvatski glazbeni zavod (HGZ).

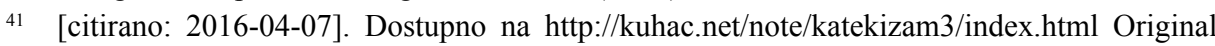
ustupio Hrvatski glazbeni zavod (HGZ).

42 Rakijaš, Branko. Nav. dj., str. 25-28.
} 
barunu Gustavu Hilleprandu Prandauu. Raspoređeno je u 40 poglavlja, a svako poglavlje ima hrvatsko-njemački rječnik. Sastoji se od elementarne teorije, osnovnih principa harmonije, oblika, imitacije i fuge, instrumenata, poglavlja o interpretaciji i partituri i dr. Drugo popravljeno izdanje objavljeno je 1889. godine i sadrži dodano poglavlje „O kajdopisu u crkvenim knjigama“, kao i prošireni njemačko-hrvatski rječnik glazbenog nazivlja. Većina izraza koje je Kuhač uveo prije sto godina i danas se upotrebljava u našoj glazbenoj praksi. Npr. sinkopa, kadenca, modulacija, period, varijacija, triola, napjev itd. To djelo prvi je iscrpan priručnik glazbene teorije u Hrvatskoj i prvi pokušaj izgrađivanja hrvatske glazbene terminologije.

Josip Haydn i hrvatske narodne popievke ${ }^{43}$ - djelo nastalo 1880. godine. Postalo je dijelom međunarodne muzikološke javnosti u povodu Kuhačeve tvrdnje o Haydnovu hrvatskom podrijetlu i njegovu odnosu prema hrvatskim narodnim napjevima koje je

Kajdopis u Slavena ${ }^{44}$ - studija postoji u Kuhačevu rukopisu u dvije verzije, predgovor prvoj verziji u kojoj je dokumentiran postanak i razvoj glazbene notacije završen je 1890. godine. Nastavljajući s proučavanjem problema povijesne notacije, donosi svoja razmišljanja o relacijama hrvatskog, srpskog i drugih slavenskih notnih pisama prema ostalim tradicijama.

Prva hrvatska uputa u glasoviranje: za djecu i za odrasle samouke $e^{45}$ - priručnik za nastavu klavira (2 sv.) objavio je 1896.-1897, uz primjenu folklorne glazbe i narodnih napjeva u vježbama.

Pjevanka ${ }^{46}$ : sto dječjih popievaka za jedno grlo s napjevi, tekstom i metodičkim uvodom. Sastoji se od metodičkog uvoda u kojem Kuhač iznosi kratke upute zašto i kako učiti djecu pjevanju u nižim razredima osnovne škole. Drugi dio sadrži 100 dječjih pjesama, narodnih napjeva, koje je izabrao Kuhač.

\subsubsection{Posebne vrste djelatnosti}

U posebne vrste djelatnosti ubraja se Kuhačev kritičarski rad uz zahtjev za odgovarajućom umjetničkom razinom izvedbi te stalnim traženjem da domaća glazbena djela pokazuju značajke hrvatske glazbene osobnosti, nedovršeni leksikoni u rukopisu, kao i vrlo opsežna korespondencija sa kopijama vlastitih otposlanih pisama.

\footnotetext{
${ }^{43}$ [citirano: 2016-04-07]. Dostupno na http://kuhac.net/note/haydn/index.html Original ustupio Hrvatski glazbeni zavod (HGZ).

44 Majer-Bobetko Sanja; Zdravko Blažeković; Gorana Doliner. Nav. dj., str. 57-78.

45 [citirano: 2016-04-07]. Dostupno na http://kgzdzb.arhivpro.hr/index.php?doctype=2\&docid $=301003978 \&$ vrstadok $=5 \#$.

46 [citirano: 2016-04-07]. Dostupno na http://kgzdzb.arhivpro.hr/index.php?doctype=2\&docid $=301004457$ vrstadok $=5$.
} 
Korespondencija ${ }^{47}$ koju je održavao s velikim brojem uglednih domaćih i stranih osoba, znanstvenika i političara od velikog je značenja za upoznavanje njegova mišljenja o različitim glazbeno-teorijskim i etnomuzikološkim pitanjima. Oko 4000 Kuhačevih pisama čuva se u arhivu Hrvatske akademije znanosti i umjetnosti u Zagrebu. Sačuvano je i oko 500 pisama što su ih Kuhaču upućivali pretežno inozemni znanstvenici.

Biografski i muzikografski (bibliografski) slovnik ${ }^{48}$ - građu je počeo prikupljati još 1857. godine u Osijeku i nastavio gotovo do same smrti 1911. godine. Metoda koju je slijedio pri pisanju raznih životopisa (hrvatski, srpski i slovenski skladatelji svih razdoblja - Blagoje Bersa, Franjo Dugan, Antun Dobronić, Josip Hatze, Dora Pejačević, Fran Lhotka, Kamilo Kolb i dr.) bila je pod utjecajem načina istraživanja tradicijske glazbe, a glavni oblik prikupljanja informacija bio je razgovor s autorom. Uz to je bilježio i njihova djela prikupljajući dokumentaciju u obliku bilježaka, pisama, isječaka iz novina ili autografa, ali izbjegavajući donošenje vlastitih sudova.

\subsubsection{Komponiranje vlastitih skladbi}

Kuhačevo glazbeno stvaralaštvo nije bilo velikog opsega, bavio se skladanjem manjih vokalnih i glasovirskih oblika. Popis skladbi koji je načinjen u okviru projekta „Franjo Ksaver Kuhač“ nastao je na osnovi spisa Moj rad, kataloga izdanja zagrebačkih nakladnika muzikalija te sačuvanih notnih materijala u Kuhačevoj Muzičko-literarnoj ostavštini u Arhivu Hrvatske (AH), knjižnici Hrvatskoga glazbenog zavoda (HGZ), Arhivu Hrvatskoga pjevačkog društva Kolo pohranjenom u HGZ (K), Knjižnici Muzičke akademije (MA) te Nacionalnoj i sveučilišnoj biblioteci u Zagrebu (NSB). Popis je podijeljen u tri dijela:

- kompozicije s Kuhačevim oznakama opusa ${ }^{49}$

- kompozicije bez Kuhačeve oznake opusa (datirane) $)^{50}$

- kompozicije bez Kuhačeve oznake opusa (nedatirane) ${ }^{51}$;

- Kompozicije drugih autora koje je Kuhač obrađivao. ${ }^{52}$

\footnotetext{
47 [Citirano: 2016-04-08]. Dostupno na http://kuhac.net/digiarchive.html\#letters. Dokumente ustupio Hrvatski glazbeni zavod.

48 Škunca, Mirjana. Kuhačevo proučavanje hrvatske glazbene prošlosti. // Zbornik radova sa znanstvenog skupa održanog u povodu 150. obljetnice rođenja Franje Ksavera Kuhača (1834.1911.). Zagreb : JAZU, 1984. Str. 417-418.

49 Blažeković, Zdravko. Popis skladbi Franje Ksavera Kuhača. [citirano: 2016-04-08]. Dostupno na http://kuhac.net/bibliografija2.html\#a.

50 Isto.

51 Isto.

52 Isto.
} 
U digitaliziranoj zbirci, osim prikupljenih tekstova i pisama, mogu se pronaći fotografije, zvučni zapisi i note. ${ }^{53}$ Nove aktivnosti koje se stvaraju na području digitalizacije uvjetovane su razvojem informacijsko-komunikacijskih tehnologija, poput širenja i zastupanja kulturne baštine u digitalnom okruženju, izrade i usklađivanja podatkovnih modela, organizacije digitalnih repozitorija te upravljanja digitalnim zbirkama.

\section{Aktivno upravljanje zaštitom - vidovi}

Kada je u pitanju organizacija i upravljanje zaštitom, posebno je naglašen suodnos dugoročne i pouzdane zaštite izvornika i zaštite digitaliziranih sadržaja. Sustavan i sveobuhvatan pristup polazi od nacionalne i institucionalne razine, a obuhvaća različite vidove ${ }^{54}$ upravljanja zaštitom pisane baštine sagledavajući vrstu i poslanje ustanove, sadržajne karakteristike fonda, potrebe korisnika, znanja i vještine osoblja, strateške dokumente ustanove i sredinu u kojoj se djeluje.

Strateško-teorijski vid donosi opis nacionalnog i institucionalnog konteksta. Strateško planiranje temelj je cjelokupnog poslovanja informacijskih i odgojno-obrazovnih ustanova (politika zaštite podrazumijeva izradu pisanih dokumenata - strategija, poslanje ustanove, program zaštite; SWOT-analiza; ustanove koje mogu poslužiti kao primjer dobre prakse; važnost teorijskih pretpostavki u edukaciji i upravljanju zaštitom baštine).

Ekonomsko-pravni vid donosi opis ekonomskog i pravnog konteksta. Unutar ekonomskog konteksta ustanove promatraju se financijski okvir i planiranje proračuna, pisani planovi koji omogućuju uvid u cjelokupne troškove i udio koji zaštita ima u tome. Pravni okvir čini skup zakonskih propisa ${ }^{55}$ koji se odnose na knjižni-

53 Isto.

54 Usp. Krtalić, Maja; Damir Hasenay. Zaštita pisane baštine u knjižnicama - analiza stanja i moguće perspektive upravljanja zaštitom hrvatske pisane baštine. // Vjesnik bibliotekara Hrvatske 54, 1/2 (2011), 60 .

55 Pravilnik o matičnoj djelatnosti knjižnica u RH. // Narodne novine 43, 715 (2001). [citirano: 2016-04-08]. Dostupno na http://narodne-novine.nn.hr/clanci/sluzbeni/2001_05_43_715. html; Pravilnik o mjerilima za utvrđivanje vrijednosti pokretnina koje imaju kulturnu, umjetničku i povijesnu vrijednost. // Narodne novine 77, 1558(2004). [citirano: 2016-04-08]. Dostupno na http://narodne-novine.nn.hr/clanci/sluzbeni/2004_06_77_1558.html; Pravilnik o određivanju kulturnih predmeta koji se smatraju nacionalnim b̄lagom država članica Europske Unije. // Narodne novine 38, 947(2004). [citirano: 2016-04-08]. Dostupno na http://narodne-novine. nn.hr/clanci/sluzbeni/2004_03_38_947.html; Pravilnik o registru kulturnih dobara. // Narodne novine 37, 652(2001). [citirano: 2016-04-08]. Dostupno na http://narodne-novine.nn.hr/ clanci/sluzbeni/2001_04_37_652.html; Pravilnik o zaštiti knjižnične građe. // Narodne novine 52, 1001(2005). [citirano: $2016-04-08]$. Dostupno na http://narodne-novine.nn.hr/clanci/sluzbeni/2005_04_52_1001.html; Ustav Republike Hrvatske (pročišćeni tekst). // Narodne novine 41, 705(2001). [citirano: 2016-04-08]. Dostupno na http://narodne-novine.nn.hr/clanci/sluzbeni/2001_05_41_705.html; Zakon o financiranju javnih potreba u kulturi: pročišćeni tekst zakona: NN 47/90, $\overline{27} / 9 \overline{3}, 38 / 09$. // Zakon.hr: pročišćeni tekstovi zakona. [citirano: 2017-09-28]. Dostupno 
ce, arhive i muzeje, zaštitu, kulturna dobra, mjerila za utvrđivanje njihovih vrijednosti (obvezni primjerak, autorska prava) i sl., ovisno o sredini u kojoj se donose.

Obrazovni vid podrazumijeva znanja i vještine ${ }^{56}$ koje su potrebne za poslovanje zaštitom, kao i oblike i načine poučavanja (stalno stručno usavršavanje osoblja, održavanje radionica s ciljem donošenja dokumenata koje svaka baštinska ustanova mora imati, studijski programi na visokim učilištima, dostupni mrežni izvori s informacijama o zaštiti i prijenosu znanja).

Materijalno-operativni vid prvenstveno se odnosi na poznavanje svojstava materijala, vrste i uzročnika oštećenja, ali i preventivne i korektivne metode tehnika i zaštite. ${ }^{57} \mathrm{U}$ tom vidu neophodno je prepletanje i ostalih nabrojenih vidova zaštite. Upravljanje zaštitom postaje posebno važno u slučajavima katastrofe, kada je potrebno imati pisane planove djelovanja (u kakvu je stanju građa, kakvi su uvjeti u skladištima, koliko se često provodi ispitivanje stanja, jesu li rezultati implementirani u poslovanje ustanove ${ }^{58}$ ).

Kulturološko-društveni aspekt očituje se u ulozi koju baštinske ustanove imaju u društvu. Povezivanje teorije i prakse očituje se u stvaranju novih usluga s naglaskom na digitalizaciji kao jednoj od metoda koncepta zaštite. Prezentacija digitalne zbirke dobar je način da se u središte pozornosti stave problemi zaštite izvornika, uvjeti prostora, preispitivanje rada neke baštinske ustanove i odgovornost svakog njezina člana. Stvaranje nacionalnog modela upravljanja zaštitom usko je povezano s razvojem strateško-teorijskog vida i strateškog planiranja. ${ }^{59}$ Osnivanje ureda kao središnjeg mjesta za sva pitanja zaštite uskladilo bi različite pojedinačne aktivnosti brojnih ustanova s ciljem njihova grupiranja. Donošenje i izrada hrvatske strategije ${ }^{60}$ digitalizacije te njezino očuvanje i zaštita omogućuju stvaranje konkretnih programa s uvrštenim načinima i kriterijima za vrednovanje

na https://www.zakon.hr/z/539/Zakon-o-financiranju-javnih-potreba-u-kulturi ; Zakon o knjižnicama. // Narodne novine 105, 1616(1997). [citirano: 2016-04-08]. Dostupno na http://narodne-novine.nn.hr/clanci/sluzbeni/1997_10_105_1616.html; Ispravak Zakona o knjižnicama 5, 66(1998). [citirano: 2016-04-08]. Dostupno na http://narodne-novine.nn.hr/clanci/sluzbeni/1998_01_5_66. html; Zakon o zaštiti i očuvanju kulturnih dobara. // Narodne novine 69, 1284(1999). [citirano: 2017-08-08]. Dostupno na http://narodne-novine.nn.hr/clanci/sluzbeni/1999_07_69_1284.html.

; Zakon o arhivskom gradivu i arhivima. // Narodne novine 105, 1617(1997). [citirano: 2017-0808]. Dostupno na http://narodne-novine.nn.hr/clanci/sluzbeni/1997_10_105_1617.html.

56 Krtalić, Maja; Damir Hasenay; Tatjana Aparac-Jelušić. Nav. dj., str. 24.

57 Usp. Haseny, Damir; Maja Krtalić. Terminološki i metodološki aspekti u proučavanju zaštite stare knjižnične građe. // Libelarium 1, 2 (2008), 203-220.

58 Mušnjak, Tatjana. Četrdeset godina konzervacije i restauracije u Hrvatskom državnom arhivu. // Arhivski vjesnik 38(1995), 197-215.

59 Usp. Krtalić, Maja; Damir Hasenay. Nav. dj., str. 61.

60 Aparac-Jelušić Tatjana: Digitalna baština u nacionalnim programima zaštite baštine. // 3. seminar Arhivi, knjižnice, muzeji: mogućnosti suradnje u okruženju globalne informacijske infrastrukture: zbornik radova / uredile Willer Mirna i Katić, Tinka. Zagreb : Hrvatsko muzejsko društvo, 2000. Str. 112-122. 
postignuća. Dosad uloženi napori (vrijeme, energija i financijska sredstva) vode prema izradi općih strategija na lokalnim i institucijskim razinama.

\section{Zaključak}

U ovom radu razrađena je problematika zaštite baštinske građe počevši od definicije pisane kulturne baštine i razumijevanja temeljnih pojmova u zaštiti s osnovnim ciljem sagledavanja stanja i percepcije zaštite te boljeg razumijevanja uz pomoć zadanih okvira koji će nas dovesti do korištenja iste terminologije. Teorijski okvir upravljanja zaštitom predstavlja polazišnu točku u proučavanju konteksta zaštite kao sastavnog dijela poslovanja knjižnica, ali i ostalih informacijsko-baštinskih ustanova. Organizacija sama po sebi podrazumijeva sustav, tj. sustavan pristup informacijama koje se grade na pojedinim stupnjevima. Pritom je naglasak na svakodnevnoj praksi i susretanju s konkretnim problemima očuvanja baštine. Stručnjaci s područja akademske zajednice zalažu se za suradnički pristup s ciljem poboljšavanja osobnih praktičnih iskustava u zaštiti baštinske građe, načinima korištenja, načinima pohrane i pravilnoj namjeni.

Prezentacija mrežnog portala Franjo Ksaver Kuhač (1834.-1911.), rezultat je izvrsnog suradničkog rada stručnjaka u suradničkim baštinskim i obrazovnim ustanovama s namjerom očuvanja i promicanja uglednog hrvatskog istraživača i utemeljitelja znanosti o glazbi u Hrvatskoj. Definiranjem i razrađivanjem pet temeljnih vidova upravljanja zaštitom (strateško-teorijski, ekonomsko-pravni, obrazovni, materijalno-operativni i kulturološko-društveni) stvorene su korisne spoznaje o aktivnom upravljanju zaštitom kao trajnim procesom ne samo pisane baštine nego i drugih korpusa baštinske građe koja se nalazi na različitim lokacijama i pohranjena je u različitim ustanovama. Definiranjem prioriteta na operativnoj razini te povezivanjem teorije i prakse stvoreni su preduvjeti za razvijanje preventivne zaštite cjelokupne baštinske građe.

\section{LITERATURA}

Andreis, Josip: Povijest hrvatske glazbe. Knjiga 4. Sveučilišna naklada Liber : Zagreb, 1989. Str. 260.

Aparac-Jelušić, Tatjana: Digitalna baština u nacionalnim programima zaštite baštine.

// 3. seminar Arhivi, knjižnice, muzeji: mogućnosti suradnje u okruženju globalne informacijske infrastrukture: zbornik radova / uredile Willer Mirna i Katić, Tinka. Zagreb : Hrvatsko muzejsko društvo, 2000. Str. 112-122. 
Bezić, Jerko. Franjo Ksaver Kuhač: začetnik glazbenoznanstvenih djelatnosti u hrvatskoj i u jugoslavenskoj glazbenoj kulturi // Zbornik radova sa znanstvenog skupa održanog u povodu 150. obljetnice rođenja Franje Ksavera Kuhača (1834.-1911.). Zagreb : JAZU, 1984. Str. 7-9.

Blažeković, Zdravko. Popis skladbi Franje Ksavera Kuhača. [citirano: 2016-04-08]. Dostupno na http://kuhac.net/bibliografija2.html\#a

Hasenay, Damir: Maja Krtalić. Dostupnost i očuvanje informacija - što znači pouzdano i dugoročno? // 12. seminar Arhivi, knjižnice, muzeji: mogućnost suradnje u okruženju globalne informacijske infrastrukture: zbornik radova / uredila Sanjica Faletar Tanacković. Zagreb : Hrvatsko knjižničarsko društvo, 2009. Str. 1-10.[citirano: 2016-04-05]. Dostupno na http://public.carnet.hr/akm/AKM_ostali/AKM12/ AKM\%2012.htm

Hasenay, Damir; Maja Krtalić. Terminološki i metodološki aspekti u proučavanju zaštite stare knjižnične građe. // Libelarium 1, 2 (2008), 203-220.

IFLA. Guidelines for digitization projects for collections and holdings in the public domain, particularly those held by libraries and archives, 2002.

Dostupno na URL http://www.kultura.hr/Sudjelujte/Digitalizacija/Korisni-linkovi Pristup: 2016-04-05.

IFLA-ina načela za skrb i rukovanje knjižničnom građom / sastavio i uredio Edward P. Adcock u suradnji s Marie-Theresom Varlamoff i Virginiom Kremp. Zagreb : Hrvatsko knjižničarsko društvo, 2003.

Ispravak Zakona o knjižnicama 5, 66(1998). [citirano: 2016-04-08]. Dostupno na http:// narodne-novine.nn.hr/clanci/sluzbeni/1998_01_5_66.html.

Katalinić, Vjera. Povijest hrvatske glazbe u razdoblju klasike - sto godina historiografskih istraživanja, ideja i sinteza: od Franje Ksavera Kuhača do Josipa Andreisa. // Zbornik radova sa znanstvenog skupa održanog u povodu 150. obljetnice rođenja Franje Ksavera Kuhača (1834.-1911.). Zagreb : JAZU, 1984. Str. 473-495. Dostupno na URL http://http://kuhac.net/bibliografija3.html Pristup 2016-04-07.

Krtalić, Maja; Damir Hasenay; Tatjana Aparac-Jelušić: Upravljanje zaštitom pisane baštine u knjižnicama - teorijske pretpostavke. // Vjesnik bibliotekara Hrvatske 54, $1 / 2(2011), 3$.

Majer-Bobetko, Sanja; Zdravko Blažeković, Gorana Doliner. Hrvatska glazbena historiografija u 19. stoljeću. Zagreb : Hrvatsko muzikološko društvo, 2009. Str. 35-36; 39; 57-78.

Mušnjak, Tatjana. Četrdeset godina konzervacije i restauracije u Hrvatskom državnom arhivu. // Arhivski vjesnik 38(1995), 197-215.

Pravilnik o matičnoj djelatnosti knjižnica u RH. // Narodne novine 43, 715 (2001). [citirano: 2016-04-08]. Dostupno na http://narodne-novine.nn.hr/clanci/sluzbeni/2001_05_43_715.html 
Pravilnik o mjerilima za utvrđivanje vrijednosti pokretnina koje imaju kulturnu, umjetničku i povijesnu vrijednost. // Narodne novine 77, 1558(2004). [citirano: 2016-0408]. Dostupno na http://narodne-novine.nn.hr/clanci/sluzbeni/2004_06_77_1558. html

Pravilnik o određivanju kulturnih predmeta koji se smatraju nacionalnim blagom država članica Europske Unije. // Narodne novine 38, 947(2004). [citirano: 2016-04-08]. Dostupno na http://narodne-novine.nn.hr/clanci/sluzbeni/2004_03_38_947.html

Pravilnik o registru kulturnih dobara. // Narodne novine 37, 652(2001). [citirano: 201604-08]. Dostupno na http://narodne-novine.nn.hr/clanci/sluzbeni/2001_04_37_652. html

Pravilnik o zaštiti knjižnične građe. // Narodne novine 52, 1001(2005). [citirano: 201604-08]. Dostupno na http://narodne-novine.nn.hr/clanci/sluzbeni/2005_04_52_1001. html

Pravilnik o matičnoj djelatnosti knjižnica u RH. // Narodne novine 43, 715 (2001). [citirano: 2016-04-08]. Dostupno na http://narodne-novine.nn.hr/clanci/sluzbeni/2001_05_43_715.html

Rakijaš, Branko. Franjo Ks. Kuhač - život i rad. Zagreb : Prosvjetni sabor Hrvatske, 1974.

Škunca, Mirjana. Franjo Kuhač kao muzički historičar. // Rad Jugoslavenske akademije znanosti i umjetnosti. Zagreb 351 (1969), 295.

Škunca, Mirjana. Kuhačevo proučavanje hrvatske glazbene prošlosti. // Zbornik radova sa znanstvenog skupa održanog u povodu 150. obljetnice rođenja Franje Ksavera Kuhača (1834.-1911.). Zagreb : JAZU, 1984. Str. 417-418.

The NINCH guide to good practice in the digital representation and management of cultural heritage materials, 2002. [citirano: 2016-04-05]. Dostupno na http://www. kultura.hr/Sudjelujte/Digitalizacija/Korisni-linkovi

Ustav Republike Hrvatske (pročišćeni tekst). // Narodne novine 41, 705(2001). [citirano: 2016-04-08]. Dostupno na http://narodne-novine.nn.hr/clanci/sluzbeni/2001_05_41_705.html

Zakon o financiranju javnih potreba u kulturi: pročišćeni tekst zakona: NN 47/90, 27/93, 38/09. // Zakon.hr: pročišćeni tekstovi zakona. [citirano: 2017-09-28]. Dostupno na https://www.zakon.hr/z/539/Zakon-o-financiranju-javnih-potreba-u-kulturi

Zakon o knjižnicama. // Narodne novine 105, 1616(1997). [citirano: 2016-04-08]. Dostupno na http://narodne-novine.nn.hr/clanci/sluzbeni/1997_10_105_1616.html

Zakon o arhivskom gradivu i arhivima. // Narodne novine 105, 1617(1997). [citirano: 2017-08-08]. Dostupno na http://narodne-novine.nn.hr/clanci/sluzbeni/1997_10_105_1617.html 
Zakon o zaštiti i očuvanju kulturnih dobara. // Narodne novine 69, 1284(1999). [citirano: 2017-08-08]. Dostupno na http://narodne-novine.nn.hr/clanci/sluzbeni/1999_07_69_1284.html

Županović, Lovro. Ilirski glazbenici: prilozi za poviest Hrvatskoga preporoda. Pretisak izd. iz 1893. godine. Zagreb : Hrvatska sveučilišna naklada, 1994.

\section{Mrežni izvori:}

Digitalna zbirka Knjižnice HAZU. [citirano: 2016-04-06]. Dostupno na http://dizbi. hazu.hr/

Etnografski muzej. [citirano: 2016-04-06]. Dostupno na http://www.emz.hr/zbirke.html Hrvatski državni arhiv. [citirano: 2016-04-06]. Dostupno na http://arhinet.arhiv.hr/_Generated/Pages/ArhivskeJedinice.PublicDetails.saps?ItemId=4722

Hrvatski glazbeni zavod. [citirano: 2016-04-06]. Dostupno na http://www.hgz.hr/

Hrvatska kulturna baština. [citirano: 2016-04-06]. Dostupno na http://kultura.hr/hr/ Zbirke/Franjo-Ksaver-Kuhac

HUMKAD. [citirano: 2016-04-06]. Dostupno na http://www.humkad.hr/

Institut za etnologiju i folkloristiku. [citirano: 2016-04-06]. Dostupno na http://www.ief. $\mathrm{hr} / \mathrm{OInstitutu/Povijest/tabid/70/language/hr-HR/Default.aspx}$

Knjižnice grada Zagreba. [citirano: 2016-04-07]. Dostupno na http://kgzdzb.arhivpro. $\mathrm{hr} /$ ?sitetext $=321$

Mrežni portal Franjo Ksaver Kuhač. [citirano: 2016-04-06]. Dostupno na http://kuhac. net/index.html

Muzička akademija Zagreb. [citirano: 2016-04-07]. Dostupno na http://kuhac.net/digiarchive/note/mojrad/index.html

Muzej grada Zagreba. [citirano: 2016-04-06]. Dostupno na http://www.mgz.hr/hr/naslovnica/

Muzej Slavonije Osijek. [citirano: 2016-04-06]. Dostupno na http://www.mso.hr/index. php?page=naslovna

Nacionalna i sveučilišna knjižnica. Zbirka rukopisa i starih knjiga. [citirano: 2016-0406]. Dostupno na http://www.nsk.hr/zbirka-rukopisa-i-starih-knjiga/

Virtualni muzej tradicijske glazbe Međimurja. [citirano: 2016-04-07]. Dostupno na http://www.mtraditional.com/kuhac.html 